\title{
Book Order Procedures In the Publicly Controlled Colleges And Universities of the Midwest
}

By FRITZ VEIT

\section{Scope of The Study}

This study is not concerned with all facets of library order work. The questions are rather focused on several large problems which were of practical concern to the inquirer, who wanted to compare certain phases of the order procedure operative at his institution with those followed at other institutions of higher learning. Before introducing these aspects of library order work, it may be well to state the limits of the study which are determined by form of control of the institutions, by their location, and by their size.

It is assumed that privately supported institutions usually are free to shape their acquisition policies in such ways as the various controlling private agencies see fit, while institutions under public control usually are bound by restrictive laws and regulations. Since such differences are presumed to exist, the investigation has been exclusively devoted to institutions under public control.

It is further assumed that geographical proximity of states would favor similarity in their governmental machinery, including regulations and practices governing library order work. This consideration has led to the geographical limitation of the study. Since the library with which the author is affliated is located in the midwest, he was particularly interested in the library acquisition patterns of this region. The study, therefore, includes only the states which form the midwestern region. There is no unanimity as to the exact limits of the
Dr. Veit is Director of Libraries, Chicago Teachers College and Wilson Junior College.

midwest. Ohio, Indiana, Illinois, Michigan, Wisconsin, Minnesota, Iowa, Missouri, Kansas, Nebraska, North Dakota, and South Dakota are the states included in this region, following the widest application of the term. ${ }^{1}$ This designation is used in the present study. However, it is conceded that the common characteristics of the several midwestern states which would favor procedures and forms common to all of them may be outweighed by the differences between them-e.g., differences in natural wealth, industrialization, urbanization, and population density. All of these differences would favor diversity in procedure.

Another factor considered in establishing the limits of the study was size of institution. Small organizations do not require a complex administrative machinery. If the organization is small, the head himself frequently performs the functions which in a larger organization are distributed among several persons. For this reason, institutions numbering fewer than three hundred students have not been treated in this study. It is granted that the cut-off point is arbitrary and that size of student body is not the only factor determining the intricacy of the administrative machinery, but this factor has been singled out because it can be isolated quite easily.

1 Columbia-Lippincott Gazetteer of the World, ed. by Leon Seltzer. (New York: Columbia University Press, 1952), p. 1199. 
This study, then, includes all types of midwestern publicly supported institutions of higher education having an enrollment of three hundred or over. Following the scheme adopted by the U.S. Office of Education in its Education Directory, the institutions are divided into four main classes in accordance with the highest level of their offerings. ${ }^{2}$

The classes are:

I. Two but less than four years of work beyond the 12th grade;

II. Only the bachelor's and/or first professional degree;

III. Master's and/or second professional degree;

IV. Doctor of philosophy and equivalent degrees.

Classification in accordance with level of training seems highly meaningful for our purposes, since, in general, book needs are influenced by level of studies. As a rule, book coverage must be both more specialized and more complete as the level of training rises. An order procedure which may be suitable for a Class I institution might not, therefore, be appropriate for a Class III or a Class IV institution. Also, while practically all of the colleges above Class I are under direct state control, the junior colleges traditionally have been under local administrative control. It must be recognized, however, that in recent years there have been significant exceptions to this principle, especially in states in which junior college programs have been introduced by special legislation or as a part of the state university system. ${ }^{3}$

The institutions of higher learning could be further subdivided by type of program offered. 4 For instance, is the junior college devoted to preparation

$2 \mathrm{U}$ S. Office of Education, Education Directory 1958/1959, Part 3: Higher Education (Washington: U. S. Government Printing Office, 1959), p. 1. This directory gives a fuller description of the several classes. 4th ed. (Washington: American Council on Education, 1956), p. 25

4 U. S. Office of Education, op. cit., p. 1-2. for advanced study or is it terminal in nature? Or, is the institution in Category II liberal arts and general, or primarily teacher preparatory? In our present study this type of program subdivision has not been considered, since a partial analysis did not reveal any significant differences in acquisition procedure between the schools of the same class offering various types of programs.

To obtain answers to the problems, questionnaires were submitted to the libraries of the various midwestern institutions of higher learning under public control which had a student body of three hundred or over. In the spring of 1959, when the study was undertaken, the number of midwestern institutions involved was 116.5 (In a few instances, institutions included in the study have branches. These branches were considered parts of the main units; therefore, no separate questionnaires were submitted to the branches.)

As may be seen from summary table, 107 libraries returned the questionnaire: 30 in Category I; 21 in Category II; 35 in Category III; and 21 in Category IV. Replies were not received from 6 in Category I; one in Category II; and 2 in Category III. All institutions in Category IV replied.

If the regional total is subdivided by states the returns are as follows:

Illinois 15 (8 in Category I, excluding 1 not reporting; 5 in Category III; and 2 in Category IV);

Indiana 5 ( 1 in I; 2 in II; and 2 in IV); Iowa 4 ( 1 in I; 1 in III; and 2 in IV);

Kansas 13 (5 in I, excluding 1 not reporting; 1 in II; 1 in III; and 2 in IV);

Michigan 16 (8 in I, excluding 3 not reporting; 2 in II, excluding 1 not reporting; 3 in III, excluding 1 not reporting; and 3 in IV);

Minnesota 7 (2 in I; 4 in III, excluding 1 not reporting; and 1 in IV);

Missouri 10 (2 in I, excluding 1 not re-

5 The selection is based on the listings under "Institutions by States" in U. S. Office of Education, op. cit. 
porting; 3 in II; 4 in III and 1 in IV); Nebraska 8 (2 in I; 5 in III; and 1 in IV);

North Dakota 6 ( 1 in I; 4 in II; and 1 in IV);

Ohio 9 ( 1 in I; 4 in III; and 4 in IV);

South Dakota 5 ( 3 in II; 1 in III; and 1 in IV); IV).

Wisconsin 10 (7 in II; 2 in III; and 1 in

The first question noted on the form which was sent to the libraries concerns the number of funds. May the library draw on one fund only, or does it have several funds available for the purchase of books? If there is more than one fund, is one clearly the principal fund and are the others subsidiary in nature (Questions I and II)? If there are subsidiary funds, are they subject to the same rules as the principal fund (Questions V, VI)?

The overwhelming majority of the respondents did not consider small gift funds as subsidiary funds. As compared to the total spent for the purchase of books, these funds were in most instances rather negligible amounts. Most of the institutions which indicated that small gifts were being received from time to time noted, nevertheless, that essentially they have just one fund, and they checked affirmatively Question I, which reads: "Do you have one book fund only?" In a few instances, responses indicated a different understanding of the question. This could, of course, be taken into account in their interpretation.

Several respondents explained that the appropriated fund was split into a number of departmental funds. They provided this information to explain in what manner the principal fund was being used. Two or three institutions reported that such an arrangement would produce several funds and checked Question II, rather than Question I, affirmatively. In this study departmental library funds which are a portion of the principal fund are not treated as separate entities but rather as components of this fund. Again, only a few questionnaire replies revealed a different interpretation, and they were adjusted.

Item III of the questionnaire was intended to reveal whether the spending of the money from the major appropriated fund was limited to one specified date, to several specified dates, or whether full leeway was granted and spending could be spread over the whole academic year.

The next item on the Questionnaire (IV, 1-3) was concerned with the channels through which orders have to move. Three main possibilities were suggested:

(I) Ordering through the central purchasing department of the proper governmental level. (In case of a library which is part of the state government, the central state purchasing agency would be considered the proper central agency; in case of a library which is part of the city government, the central city purchasing agency would be so treated, etc.)

(2) An arrangement which would involve the purchasing department of the college or university.

(3) Direct purchasing by the library itself.

In respect to central purchasing, the analysis revealed differences in interpretation of this concept. In several instances, libraries in Category I noted that they ordered through the purchasing department of the board of education of the city's public schools. Some respondents considered this purchasing department as a central purchasing department (IV-l), others treated it as if it were a purchasing department of a college (IV-2). In order to assure uniformity of approach, in this study, all of these instances have been viewed as involving a central purchasing department (IV-l). In the summary, they are, therefore, recorded in the column entitled "Central," but, in addition to being included in this column, they are also separately enumerated in the column headed "Bd. of Ed." 
It should be noted that the first three sub-entries under IV are not necessarily mutually exclusive categories. If, for instance, an order may not be placed directly by the library order department (Item IV-3), but must be placed through the state (or district, or municipal) central order department (IV-I), it may, nevertheless, have to be first channeled either through the library order department (IV-3) or through the order department of the college (IV-2) before it reaches the central order department.

A number of libraries indicated that more than one level was involved by checking not only one (IV-1; or IV-2; or IV-3) but two or even all three of these sub-entries. In tabulating the questionnaire returns, only the highest level involved was recorded. For instance, if both IV-1 and IV-2 were checked by a respondent only $I V-2$ was recorded in our tabulations.

It was further considered important to discover whether only the library was charged with the ordering of library books, or whether books might also be ordered directly by teaching departments without involving the library at all. (IV-4).

Another problem to which an answer was sought concerned the carrying over of funds. Do all moneys appropriated for a certain fiscal period have to be expended during this period or may funds be carried over into subsequent periods? Under Question IV-5, the respondents were asked to "specify." Nearly all gave an explanation of their practice. They distinguished between the encumbered and the unencumbered portion of the balance. The encumbered balance was treated as if it had been spent during the current fiscal year even if payment was to occur in the course of the subsequent fiscal year. "Unexpended" was used by nearly all respondents in the meaning of "unencumbered." This interpretation has also been adopted in our study; in Question IV-5, "unexpended balance" should therefore be interpreted to mean "unencumbered balance."

\section{State-By-STATE Comparison ${ }^{6}$}

If a state-by-state comparison is made, distinct differences are immediately apparent. Only 9 of the 12 states have institutions of Type I. (They are lacking in Ohio, South Dakota, and Wisconsin.) Type II institutions are found in even fewer states: 7 of the 12. (They are lacking in Illinois, Indiana, Iowa, Minnesota, Nebraska.) All states but North Dakota have at least one representative of Type III, and one of Type IV has been established in each of the states forming the midwest.

Turning to book funds, we find that most states favor one single book fund for their libraries, while in some states subsidiary funds are received by libraries of various types. Subsidiary funds occur with greatest frequency in Ohio, North Dakota, and Michigan, in that order. Scattered examples of subsidiary funds may also be found in Illinois, Minnesota, Missouri, and South Dakota. The subsidiary funds of the two Illinois institutions which are under board of education control-one of Type I and one of Type III-are derived from student fees. The same holds true for the one Missouri institution which is under board of education jurisdiction.

All in all, there are only five instances in which book orders must be placed at specified periods, one instance each in the following states: Illinois, Kansas, Michigan, Minnesota, and Wisconsin. The institutions involved are in Category I, except for the one in Wisconsin, which is in Category II.

\footnotetext{
a The original study includes a table for each of the midlwestern states. These tables carry the same items for the various states as the summary table does for the whole midwest. In the original, the textual state-by-state analysis is also somewhat more extensive. As long as analysis is also somewhat more extensive. As long as the limited supply lasts, interested persons may obtain lege, $6800 \mathrm{~S}$. Stewart Avenue, Chicago 21, Illinois.
} 
The channeling of orders shows considerable variation if comparisons are made on a state-by-state basis. Michigan, Missouri, and Wisconsin-except for their Type IV institutions-reveal participation of a central purchasing agency as the predominant, though not exclusive, pattern. In the other states, the central purchasing agency is either not involved at all or only for certain types of institutions, again usually not exclusively for any of the categories. In Kansas, for instance, only the two Type III institutions and two of the four Type I institutions which responded to the questionnaire noted involvement of a central purchasing agency. Similarly, Illinois is represented by only two institutions of Type I and one of Type III; Iowa and Nebraska by one Type I institution each, and South Dakota by one in Category II. In the various states, all Type IV institutions may place orders directly through their respective library order departments with the one single exception in which the college purchasing department is employed. Except for Michigan, Missouri, and Wisconsin, Type III libraries most frequently place their orders either directly through their own order departments or, as the second favored procedure, through their college purchasing office.

With regard to the next item on the questionnaire- "Is the Library the Sole Agency for Ordering of Library Books?" -no significant differences were revealed from state to state. In all states the prevailing pattern for all types of libraries was that the library had sole charge of book purchases. Also, the next query, which related to the carrying over of the balance from one fiscal year to the other, did not show state patterns varying distinctly from each other. In all states but one, Nebraska, the preponderant practice was to disallow the carrying over of the unspent balance into subsequent fiscal years. Noteworthy variations from the pattern, in addition to Nebraska, were found in Kansas and Michigan. In Kansas, 3 institutions out of 12 , in $\mathrm{Ne}$ braska 5 out of 8 , and in Michigan, 4 among the 16 institutions, reported that they might carry over such funds. The three Kansas institutions are of Type I; in Nebraska one is of Type I, and four are of Type III; and in Michigan one is of Type I, one of Type III, and two are of Type IV. It should again be emphasized that this question does not cover subsidiary funds, such as funds derived from fees. With regard to subsidiary funds, a considerable number of the institutions observed that time limitations did not apply.

\section{The Regional Pattern}

In evaluating the library order procedure of the publicly supported institutions of higher learning for each of the several states, we have discovered definite trends with regard to various aspects of the procedure. An inspection of the summary table including all midwestern states presents certain trends in even clearer focus.

Of the 107 midwestern institutions which supplied data for our inquiry, 84 have essentially only one fund at their disposal. Twenty-three of the institutions have a principal as well as subsidiary funds. As has been explained before, the gift funds which represent a negligible percentage of the total spent for books are not viewed as separate subsidiary funds.

It is quite evident that the institutions with the more varied and more complex book requirements are more likely to have subsidiary funds then the others. Nine of the 21 Type IV institutions indicate that they have such funds, while only 2 of 30 Type I institutions obtain funds from more than one source. The table reveals further that institutions of Types II and III include a higher percentage of libraries with subsidiary funds than those of Type I. In 14 of the 23 instances, the libraries with subsidiary 
funds derive these allotments in whole or in part from various forms of student fees. These are frequently general curricular fees but graduate, psychology, education, and other special subject fees are also mentioned as sources for the subsidiary funds. Student fees are especially favored by libraries of Categories II and III. In Category IV, only 2 indicate that fees are their subsidiary sources, while others report gift funds and endowed funds of considerable magnitude. Rotary funds of significant size, for fines and replacements, are also listed in a few cases.

As to the periods during which orders may be placed, there is practically complete uniformity among the libraries of the region. Out of 107, 102 may order books anytime during the period for which the fund is appropriated. Only one Type I library is compelled to concentrate all its orders on a specified date. One Type II and three Type I libraries are limited to several specified dates. Obviously, it has been recognized on all levels of college and university administration that the libraries must have the freedom to order whenever thr need arises during the academic year.

There is considerable variety among the libraries with regard to the channels through which the orders must pass. About a third of the group-37 of 107 -may order books through the library's own order department. About another third-36 of 107-must avail themselves of the services of a central order agency. This latter group includes 15 institutions which use as their agency the Board of Education under whose respective jurisdiction they are. The remaining $33 \mathrm{li}$ braries utilize the facilities of their college or university business office. It has been emphasized earlier in this study that only the highest level is tabulated and that in several instances more than one level is involved. A library which must order through a central state agency may have to forward the orders through the college business office. In this case, however, only the "Central" column has been checked as applying. It is interesting to note that there is a significant difference between the several categories with regard to the channels utilized. Of 21 Type IV institutions, 20 handle the orders through their library's own order department; one uses the university's business office: Among the 35 Type III institutions, we find that the college business office is designated in 14 instances.

The library's own order department and the central purchasing department are represented with 11 instances and one instance respectively. In one of the cases which were recorded under central purchasing department, the Board of Education is considered as the central agency. Of 21 Type II institutions, only one orders through the library's order department. The college business department appears in 9 instances and the central purchasing department is represented 11 times. Only 1 of these-as was the case with the Type III institutions-channels the orders through the Board of Education. Fifteen of the 30 institutions included in Category I report that they use a central purchasing department. In 13 instances of the 15 which utilize a central department, the Board of Education (municipal, or other subordinate governmental level) is the agency. In 9 instances, Type I institutions use the college business office as their purchasing agents; 5 of the Type I libraries may order directly through their order departments.

The questionnaire which encouraged the respondents to comment on any aspect of the procedure elicited a number of emphatic statements in the matter of channeling of orders. High satisfaction was expressed by libraries which are permitted to order directly. The librarian of one institution included in this study described how, in gradual fashion, the library's order department had been given an increasing number of book or- 
der functions and how it will eventually assume practically all of the book order responsibilities-a change which appears to be highly advantageous to the library as well as the university's purchasing department. ${ }^{7}$ On the other hand, in several instances in which libraries had to forward orders to a state purchasing department which, in turn, had to send them to a jobber or publisher, strong dissatisfaction was expressed about slowness with which the books reached the library.

The next question brought nearly identical replies. Ninety-eight of 107 libraries reported that they were the sole agencies for the ordering of library books. The only notable exceptions were six of the 30 Type I institutions. The overwhelming majority of the institutions which were considered the sole agencies said that occasionally departments used some of their own non-library funds to acquire books which were treated as laboratory tools. These items might be manuals or clippings, some special dictionaries or occasionally even textbooks. In most, though not all, institutions materials so acquired do not become part of the library's collection. A few libraries reported that departments which had this privilege were required to order books through the library even if their own non-library funds were involved. In other cases, departments must utilize the general college business office for these transactions.

The next question revealed again a nearly uniform practice. Most libraries, 92 of 107 , noted that they were not allowed to carry over into subsequent years the unencumbered balance of the appropriated fund.

With regard to the subdiary funds, the practice varied. Most of the libraries which had funds from other sources-for instance, fees-frequently added that the restrictions which applied to the appro-

7 Sidney E. Matthews, "Simplifying, Library Acquisitions with University Purchasing," CRL, XVIII (1957), 331-334. priated fund did not affect the subsidiary funds.

Since only a limited number of institutions have more than one fund available, only 31 responses were received to the question "Does the Order Procedure for the Major Appropriated Fund Apply to Subsidiary Funds?" (The 23 listed in the Column "Principal and Subsidiary Funds" were joined by seven institutions which had minor gift funds but not "subsidiary funds," according to the definition we adopted.) Twenty-one followed the same procedure for both, and ten noted that they preferred to follow a different, usually simplified, order pattern for subsidiary funds.

\section{Conclusions}

As stated in the introductory chapter, the study was based on data supplied by publicly supported colleges and universities of the midwest. Since we interpreted "midwest" in a broad sense, we included in this region as many as twelve states. While these states have certain characteristics in common which may favor similarities in procedures, they differ in such important factors as natural wealth, population density, and degree of industrialization-all factors likely to cause diversity in the patterns of the governmental machinery.

Whether the sample is sufficiently diversified to represent a cross section of the United States scene cannot be stated with certainty. This question can be answered with greater confidence as similar studies covering other regions of the U.S. become available. It is hoped that such studies will be undertaken.

While studies which give a broad view of the order procedures in large segments of our country would be valuable, it would also be highly desirable if investigators concerned themselves thoroughly with individual institutions. Case studies could deal at length with details of a specific procedure and, by probing deeply, could possibly establish causes for exist- 
SUMMARY: ALL MIDWESTERN STATES

\begin{tabular}{|c|c|c|c|c|c|c|c|c|c|c|c|c|c|c|c|c|}
\hline \multirow[t]{2}{*}{$\begin{array}{l}\text { Cate- } \\
\text { gories }\end{array}$} & \multirow[t]{2}{*}{$\begin{array}{l}\text { Num- } \\
\text { ber in } \\
\text { Cat. }\end{array}$} & \multicolumn{2}{|c|}{ Book Funds } & \multicolumn{3}{|c|}{ Order Periods } & \multicolumn{4}{|c|}{ Channeling of Orders ${ }^{r}$} & \multicolumn{2}{|c|}{$\begin{array}{l}\text { Library } \\
\text { Sole } \\
\text { Agency: }\end{array}$} & \multicolumn{2}{|c|}{$\begin{array}{l}\text { May Carry } \\
\text { Over Bal- } \\
\text { ance }\end{array}$} & \multicolumn{2}{|c|}{$\begin{array}{l}\text { Same Proc. } \\
\text { for Subsid. } \\
\text { Funds }\end{array}$} \\
\hline & & $\begin{array}{l}\text { One } \\
\text { Only }\end{array}$ & $\begin{array}{l}\text { Subsid. } \\
\text { also }\end{array}$ & $\begin{array}{l}\text { One } \\
\text { Date }\end{array}$ & $\begin{array}{c}\text { Several } \\
\text { Dates }\end{array}$ & $\begin{array}{l}\text { Any- } \\
\text { time }\end{array}$ & $\begin{array}{l}\text { Cen- } \\
\text { tral }\end{array}$ & $\begin{array}{l}\text { Bd. } \\
\text { of } \\
\text { Ed.t }\end{array}$ & $\begin{array}{l}\text { Col- } \\
\text { lege }\end{array}$ & $\begin{array}{l}\text { Lib- } \\
\text { rary }\end{array}$ & Yes & No & Yes & No & Yes & No \\
\hline $\begin{array}{l}\text { I } \\
\text { II } \\
\text { III } \\
\text { IV }\end{array}$ & $\begin{array}{l}30^{x 1} \\
21^{x^{2}} \\
35^{x 3} \\
21\end{array}$ & $\begin{array}{l}28 \\
16 \\
28 \\
12\end{array}$ & $\begin{array}{l}2 \\
5 \\
7 \\
9\end{array}$ & 1 & $\begin{array}{l}3 \\
1\end{array}$ & $\begin{array}{l}26 \\
20 \\
35 \\
21\end{array}$ & $\begin{array}{l}15 \\
11 \\
10\end{array}$ & $\begin{array}{r}13 \\
1 \\
1\end{array}$ & $\begin{array}{r}9 \\
9 \\
14 \\
1\end{array}$ & $\begin{array}{r}5 \\
1 \\
11 \\
20\end{array}$ & $\begin{array}{l}24 \\
20 \\
34 \\
20\end{array}$ & $\begin{array}{l}6 \\
1 \\
1\end{array}$ & $\begin{array}{l}5 \\
1 \\
5 \\
3\end{array}$ & $\begin{array}{l}24 \\
20 \\
30 \\
18\end{array}$ & $\begin{array}{r}3 \\
5 \\
5 \\
14\end{array}$ & $\begin{array}{l}5 \\
1 \\
3 \\
1\end{array}$ \\
\hline & 107 & 84 & 23 & 1 & 4 & 102 & 36 & 15 & 33 & 37 & 98 & 8 & 14 & 92 & 27 & 10 \\
\hline $\begin{array}{l}t= \\
:= \\
:= \\
1= \\
\times 1= \\
\times 2= \\
\times 3=\end{array}$ & $\begin{array}{l}\text { Of the } \\
\text { In Cate } \\
\text { In Cate } \\
\text { The Lib } \\
=\text { Exclud } \\
=\text { Exclud } \\
=\text { Exclud }\end{array}$ & $\begin{array}{l}\text { ubsidi } \\
\text { gory I } \\
\text { gory I } \\
\text { raries } \\
\text { ing six } \\
\text { ing on }\end{array}$ & $\begin{array}{l}\text { ary funds } \\
\text { under " } \\
\text { I, under } \\
\text { listed in } \\
\text { non-repo } \\
\text { non-rep }\end{array}$ & $\begin{array}{l}\text { the } \\
\text { Chan } \\
\text { "Libr } \\
\text { this c } \\
\text { rting } \\
\text { orting } \\
\text { ortin }\end{array}$ & $\begin{array}{l}\text { ollowing } \\
\text { eling of } \\
\text { ry Sole A } \\
\text { lumn are } \\
\text { institutio } \\
\text { institutio }\end{array}$ & $\begin{array}{l}\text { inclu } \\
\text { Order } \\
\text { Agenc } \\
\text { also }\end{array}$ & $\begin{array}{l}\text { fee } \\
\text { onl } \\
\text { onl } \\
\text { unte }\end{array}$ & Is: 1 & $\begin{array}{l}2 \text { in } \\
30 \\
21\end{array}$ & $\begin{array}{l}\text { al } \\
\text { port } \\
\text { por }\end{array}$ & & & I & & & \\
\hline
\end{tabular}

ing practices, for both those deemed effective and those deemed inadequate. With sufficient evidence on hand, it should then be more easily possible than it is today to introduce and maintain practices which produce full user satisfaction at small expenditure of money and time.

\section{ACRL Meetings At Midwinter}

The ACRL board of directors will meet twice at the Midwinter meeting of ALA -at 10:00 A.M. Monday, January 29, and 10:00 A.M. Tuesday, January 30. The Steering Committee of the College Libraries Section will meet at 4:30 P.M. Tuesday, January 30, to be followed by dinner at 6:30 P.M.; the Steering Committee of the Junior College Libraries Section will meet at 8:30 P.M. January 29; the Subject Specialists Section Steering Committee will meet three times-8:30 A.M. and 8:00 P.M. January 29, and 2:00 P.M. January 30; the SSS Law and Political Science Subsection will have a meeting of its Steering Committee at 4:30 P.M. January 29; the Steering Committee of the University Libraries Section will meet at 8:00 P.M. January 29; the ULS Research and Development Committee will meet at 4:30 P.M. January 29, and the ULS Committee on Urban University Libraries will meet at 4:00 P.M. January 30 .

ACRL committees scheduled to meet Monday, January 29, are: Conference Program Committee (4:30 P.м.); Publications Committee (8:30 A.M.); Committee on Standards (8:30 P.M.). Scheduled to meet Tuesday, January 30, are: Committee on Appointments and Nominations (4:30 P.M.); Advisory Committee To Administer the Burmese Projects (12:30 P.M. luncheon meeting); Grants Committee (2:00 P.M.). Meeting on Wednesday, January 31, are: Advisory Committee on Educational and Professional Organizations (10:00 A.M.); National Library Week Committee (8:30 P.M.); ACRL/ARL Metcalf Project Advisory Committee (12:30 P.M. Iuncheon meeting). Thursday, February 1, there will be a meeting of the Organization Committee at 8:30 A.M. 